
\title{
R Research S Suare \\ Experimental evaluation of the shear behavior of large landslide slip zone using Multistage - Multiphase shearing method.
}

Ephrem Getahun ( $\nabla$ ephrem.getahun@amu.edu.et )

Arba Minch University

Shengwen Qi

Institute of Geology and Geophysics Chinese Academy of Sciences

\section{Songfeng Guo}

Institute of Geology and Geophysics Chinese Academy of Sciences

\section{Zhenming Shi}

Tongji University

\section{Research}

Keywords: Landslide, Multistage - multiphase shear mode, shear behavior, Shear rate, Slip zone

Posted Date: June 26th, 2020

DOl: https://doi.org/10.21203/rs.3.rs-37863/v1

License: (c) (i) This work is licensed under a Creative Commons Attribution 4.0 International License. Read Full License 


\section{Abstract}

Abstract The study of shear behaviors comprises of the analysis of shear deformation characteristics and strength parameter determinations. Understanding the constitutive behaviour of shear zone soil samples is essential for evaluation of the critical shear behaviors of reactivated landslides, through considerate experimental tests. The experiment was carried out based on the multistage - multiphase shear technique via ring shear apparatus. The main advantage of this new method is to examine the same soil specimen for progressive loading and the continuous phases of shearing. The result shows that two major shear characteristics under the multiphase shear mode; the first is a postpeak shear weakening behavior of the soils on the last phase shear process, it indicated a decrease in friction resistance on fast rate effects, which enables to narrate with fastly moved coseismic landslide behaviors. The other one is a practical increase in friction coefficient values (hardening behavior) on the entire shear process as the rate increases. This shear resistance scenario can also be related with the stabilization mechanism of landslide slip surface soils against sliding.

\section{Key Points:}

- Multistage - Multiphase shearing method using ring shear test is an appropriate approach to analyze the critical shear behavior of large coseismic landslide soils.

- Large shear displacement and fast rate experiment influences are shown on the slip zone soils by displaying post peak shear weakening and hardening behaviors on the entire shear process.

- The shear hardening behavior of landslide slip zone soils was caused by soil microfabrics response for progressive shearing, which may narrates with stabilization mechanism of landslide runout.

\section{Introduction}

The shear strength of soils depicted great attention on its significance to various engineering structures and natural slopes (Bhattacharya et al. 2017; Eid et al. 2015; Kalteziotis 1993; Mesri and Shahien 2003). Numerous studies were carried out to investigate the shear behavior of largely displaced landslides through different experimental mechanisms (Gratchev and Sassa 2015; Habibbeygi and Nikraz 2018). It is expected that the soil skeleton, particle size distribution, and displacement rate have considerable effect on the frictional strength of soils (Gratchev and Sassa 2015; Habibbeygi and Nikraz 2018; Mersi and Olson 1970). Moreover, studying the shear behavior of a reactivated landslide soils involves the analysis of shear deformation characteristic and strength parameter determinations.

Understanding the constitutive behavior of shear zone soil samples is essential for evaluation of the critical shear behaviors, through considerate experimental tests. Shear strength analysis of soils from the slip zones of an existing landslide is one of the most important parameters to evaluate the landslide reactivation mechanisms (Li et al. 2017; Wen and Ji 2019). Slip zones of landslides are natural shear zones produced under variable stress levels, and propagate through different types of heterogeneities (Wen and Aydin 2004). Therefore, analysis of shear behavior of natural slip zones should reveal a more realistic and complex history of the landslide processes. Moreover, the shear behavior of slide zone soils usually results from the particle level characteristics and the shear processes, it is intuitively recognized that particle size and shape affects soil shear behavior.

The conventional shear approaches used by several researchers circle on a single stage or multi stage loading, and apply a certain shear displacement to an individual samples, it uses more sample specimens for planned tests. There is no research so far considered the incremental phase of shearing in a different normal stresses. We designed a multistage - multiphase shearing technique that can test a single soil specimen to be sheared for continuous 
incremental large displacement with simultaneous fast rate, under different normal loading. It assesses the shearing behavior of soils under such progressive deformation characteristics and failure conditions.

The study mainly aims to evaluate and learn the multistage - multiphase shearing technique on the determination of critical shear strength behavior of shear zone soil samples using an automated suction controlled ring shear test apparatus. With the application of multiphase shear mode, it assesses the effects of shear rate on the residual shear behaviors, internal friction angle, and shear deformation characteristics of soil specimens.

\section{Experimental Methods}

Long runout coseismic landslides do exhibit progressive increment of slide mobility from detachment and initiation phase to a higher speed of slide mass with down throw and ejection seismic forces, as the displacement increases (Getahun et al. 2019). Moreover, after large displacement, braking and stabilization of the runout landslides occurs. To emulate this real phenomenon and conceptual model of the landslide runout, a multiphase shear mode was designed. A multistage multiphase shear technique is implemented on a single soil specimen, with incremental normal loads to consolidate and applies a continuous progressive large shear displacement and rate. This new approach was applied on samples collected from the reactivated landslide shear zone soils.

The study consists of detail field inspection, measurements, and soil samplings. The soil samples were collected from the shear zone of the Chenjiaba Landslide, which was induced by the 2008 Wenchuan earthquake. Soil physical property tests comprising of the moisture content, density, grain size distribution of the samples were carried out first in the index laboratory. Disturbed samples were used to prepare specimens for ring shear tests according to the standard procedures. The Unified Soil Classification System (USCS) standards for grading soils were used to characterize the soil sample type (ASTM-D2487-11 2011). In this research, the samples used are natural soils trimmed from shear zone of Chenjiaba landslides, and graded as mixture of some gravel and fines with sandy soils.

To observe and understand the particle arrangement after shearing test, scanning electron microscope (SEM) imaging tests were used to know the micro fabric nature. In SEM, the surface of the soil is scanned using a high energy beam of electrons which provides an 'image' of the soil, then allowing a view of the soil's microstructure. It is a method used for high-resolution imaging of samples surfaces. The SEM imaging tests of samples from the shear zone of the landslide are analyzed at different scales ( $1 \mathrm{~mm}, 500 \mu \mathrm{m}, 200 \mu \mathrm{m}, 100 \mu \mathrm{m}$, and $50 \mu \mathrm{m})$ magnifications to understand the particles microfabric setup and arrangement. The Scanning electron microscope (SEM) equipment used in this research was Nova Nano SEM 650.

\subsection{Multistage - Multiphase shearing approach}

The stabilization of long runout landslide mostly occurs along shear zone, after large displacements. So, the experimental design to achieve the residual shear behavior of soils is considered on the progressive large displacement rate test to the reactivated soils, and evaluates the shear response of the soils under the experiment. The shear resistance developed for long runout landslide was, reasonably, from the critical shear strength of the shear zone soils (Hu et al. 2018). Unlike the conventional shear strength tests that use several soil specimens, a multistage test use a single soil specimen and shear the sample in stages with increasing confining stresses (Mairaing 2008; Nam et al. 2011). In order to learn the stabilization mechanisms of long runout landslides along the shear zone, we modified and designed a multi stage multiphase shear process to evaluate the continuous shear behavior of reactivated slip zone soils.

The multistage ring shear test type was one of the procedures used to measure the residual shear behavior of soils (Bhat et al. 2013; Binod and Hideaki 2004; Hoyos et al. 2014; Kalteziotis 1993; Nam et al. 2011; Stark et al. 2014; Stark 
and Vettel 1992; Wang et al. 2017). These studies (Binod and Hideaki 2004; Harris and Watson 2003; Meehan 2007; Meehan et al. 2008; Stark and Vettel 1992; Tiwari et al. 2005) have mentioned multistage ring shear tests in their respective research on large shear displacement, and depicted that the residual shear intercepts were decreased (Binod and Hideaki 2004), and have the lowest measured residual strength (Stark and Contreras 1996; Stark and Vettel 1992) that permit unlimited continuous shear displacement.

The general approach of this research method consists of three stages of normal loading, and four phases of shearing on each stages of normal loading. After the initial consolidation attained by intended normal stress, shearing proceeds with designed shear rates, times and targeted angular degree or shear displacement. The new approach of multistage multiphase shearing tests were carried out through progressive increasing normal loads, with an initial loading of $60 \mathrm{kPa}$, and double increased for the second and third stage of consolidation. The consolidation time given to each stage of loading was equal with varied rates. These loading plans were made based on the slide soil average thicknesses $(10 \mathrm{~m})$ and average density $\left(2.4 \mathrm{~g} / \mathrm{cm}^{3}\right)$ of the soil samples from the field sites investigation. The tests were conducted in drained conditions.

Table 1

details of the multistage - multiphase ring shear testing schemes.

\begin{tabular}{|c|c|c|c|c|c|c|}
\hline $\begin{array}{l}\text { Consolidation stages via applied } \\
\text { Normal stresses (kPa) }\end{array}$ & $\begin{array}{l}\text { Consolidation rate } \\
\text { (kPa/min) }\end{array}$ & \multicolumn{4}{|c|}{$\begin{array}{l}\text { Shear phases (designed shear } \\
\text { displacements (mm) }\end{array}$} & $\begin{array}{l}\text { Time } \\
\text { (min) }\end{array}$ \\
\hline 60 & 20 & \multirow[t]{3}{*}{40} & \multirow[t]{3}{*}{80} & \multirow[t]{3}{*}{160} & \multirow[t]{3}{*}{320} & \multirow[t]{4}{*}{3} \\
\hline 120 & 40 & & & & & \\
\hline 240 & 80 & & & & & \\
\hline Shearing rate $(\% / \mathrm{min})$ & & 13.2 & 26.4 & 52.8 & 105.6 & \\
\hline
\end{tabular}

The study site condition was an earthquake triggered, fastly moved and long runout landslides (Huang et al. 2017; Wu et al. 2010; Xing et al. 2015), and experiences of some studies that practiced shear tests on large landslides are used as a baseline to plan for multistage multiphase shear approach. The multiphase shear approach considers an initial shear displacement of $40 \mathrm{~mm}$ and rate of $13.2 \mathrm{~mm} / \mathrm{min}$ on the first phase, and these proceeds with a double increment to next phases (Table_1).

\subsection{Ring shear apparatus and test procedures}

The frequent challenges of studying the deformation characteristics in large shear displacements and critical strength have paved the way for the development of ring shear apparatus. Several ring shear apparatuses were designed and used to determine the shear strength behaviors of soils since the 20th century. The historical development of the apparatus was noted from its instigated to recent improvements (Cui et al. 2016; Mackay et al. 2012; Stark and Contreras 1996; Tiwari and Ajmera 2011; Tiwari et al. 2005). The outline of the ring shear device was introduced (Hvorslev 1939), and its concept utilized and improved by Bishop et al. (1971) that provided a useful overview and designs for other researchers.

Bromhead ring shear apparatus (Bromhead 1979) was a kind of one sample box apparatus that facilitated its applicability to engineering practices, modified by (Stark and Contreras 1996; Stark and Eid 1993; Stark and Vettel 1992) and used to measure the drained residual strength of cohesive soils. Ring shear apparatus used in Japan since 1984 (Setiawan et al. 2015; Yin et al. 2016) (Disaster Prevention Research Institute (DPRI) version 1-7) for the investigation of liquefaction flows in landslides and seismic response of landslip materials at large shear displacement has been progressively developed. The ring shear apparatus used herein was the Modified form where originally based from Ring 
shear apparatus developed by Bromhead (1979). It consists of two automated servo-controlled actuators: one pneumatic actuator for normal loads and one electrical actuator for shear loads.

The apparatus consists of three main components: (a) Main cell with rotational shear system; (b) data acquisition/ process control (DA/PC) system with performance/ data reduction software for real-time calculations of shear stress and average linear displacements; (c) Suction control panel. Main cell includes upper and lower platen sample boxes, Pneumatic servo-controlled actuator for application of vertical loads, electrical servo-motor actuator for application of torsional loads, linear variable differential transducer (LVDT) to measure vertical deformations, electrical sensors for real-time measurements of shear torque, shear angular deformation and vertical load, adjustable top and bottom stainless-steel loading platens, and, reinforced-acrylic confining cell with 1000-kPa air pressure capacity (Hoyos et al. 2010, 2014) (Fig. 2). .

The experiment begins with the preparation of samples, depending on the intended test, samples need to be oven dried for basic physical property and drained ring shear tests. During ring shear tests, soil samples required to conform to the annular space between the two concentric rings of the lower platen. The setup of the lower sample annular stainless steel platen has $152.4 \mathrm{~mm}$ outer diameter and $96.5 \mathrm{~mm}$ inner diameter and an average height of specimen $20 \mathrm{~mm}$. The inside to outside diameter ratio is 0.63 as per ring shear testing standard (ASTM-D6467-13 2013).

In the apparatus, an air actuator applies the axial load (normal force), torque, axial shortening, and rotation speed were recorded depending on experiment duration (Kitajima et al. 2010). The designed input parameters for consolidation and shearing are set. According to the plan to this experiment, consolidation of specimen for specified normal stress ( $\mathrm{kPa}$ ) and rate initially done, after consolidation finished at the intended time then shearing test takes place according to the designed shear rate (System can do $0.001 \%$ Min (minimum rate) and $360 \%$ min (maximum rate)) and targeted angular degree (shear displacement). Lastly, using the automated DA/PC system all required data are properly checked and saved on the computer data storage, and then the data's were extracted for further analyses, plots and interpretation.

\section{Results}

\subsection{Soil gradation characterizations}

The soil shear behavior analysis has been linked with grading, shape and other physical properties. Grain size distribution (GSD) is the most fundamental type of physical property in soil studies (Yong 2017). The gradation characteristics parameters of the soils are described based on the unified soil classification system; it includes the effective grain diameters passing through $10 \%\left(D_{10}\right), 30 \%\left(D_{30}\right), 60 \%\left(D_{60}\right)$ and calculated coefficient of uniformity $(C u)$ and coefficient of curvature (Cc) (Table 2). The soil samples were collected at different horizontal basal slip surface, where exposed at deep river cut in contact with massive sandstone unit during field inspections. 
Table 2

Basic physical properties and gradation characteristics of soil sample

\begin{tabular}{|c|c|c|c|c|c|c|c|c|c|c|c|}
\hline \multirow[t]{2}{*}{$\begin{array}{l}\text { Samples } \\
\text { Id }\end{array}$} & \multirow{2}{*}{$\begin{array}{l}\text { Moist. } \\
\text { Content } \\
(\%)\end{array}$} & \multirow{2}{*}{$\begin{array}{l}\text { Density } \\
\left(\mathrm{gm} / \mathrm{cm}^{3}\right)\end{array}$} & \multicolumn{3}{|c|}{$\begin{array}{l}\text { Grain size distribution } \\
(\%)\end{array}$} & \multicolumn{5}{|c|}{ Soil gradation parameters } & \multirow[t]{2}{*}{$\begin{array}{l}\text { Soil grading } \\
\text { characteristics }\end{array}$} \\
\hline & & & $\mathrm{Gr}$ & Sand & $\begin{array}{l}\text { Fines } \\
(\mathrm{M} / \mathrm{C})\end{array}$ & $\mathrm{D}_{10}$ & $D_{30}$ & $D_{60}$ & $\mathrm{Cu}$ & $\mathrm{Cc}$ & \\
\hline Ch04 & 8.39 & 2.15 & 21.2 & 78.6 & 0.2 & 0.30 & 0.65 & 2.80 & 9.33 & 0.50 & SP \\
\hline Ch06 & 10.84 & 2.1 & 19.8 & 80.0 & 0.2 & 0.30 & 0.60 & 2.50 & 8.33 & 0.48 & SP \\
\hline Ch07 & 9.41 & 2.38 & 12.2 & 87.6 & 0.2 & 0.28 & 0.45 & 1.30 & 4.64 & 0.56 & SP \\
\hline \multicolumn{12}{|c|}{$\begin{array}{l}\text { Notes: *Symbols denotes moisture content (MC), Gravel (Gr), fines comprised of silt (M) and Clay (C), soil grading } \\
\text { terms are denoted by poorly graded sand with some fine soils (SP). Grain diameter passing through 10\% (D10), 30\% } \\
\text { (D30), 50\% (D50), and 60\% (D60), Coefficient of uniformity (Cu), and Coefficient of curvature (Cc). }\end{array}$} \\
\hline
\end{tabular}

The soil samples of the study area were characterized by poorly graded sandy soil with some gravel and fine mixtures, which have dark yellow to light gray weathered colors. The grain size distribution plot shows that soils are uniformly sorted with certain difference in its grading parameters. Moreover, sample Ch-07 has shown fine sand dominated soils compared to other samples from the soils grading curve. During the multiphase ring shear experiment, the grain size, shape, and their arrangement has showed substantial effects in the shear stress values corresponding with the continuous shear displacement rate on the soil samples. The grain size distribution curve of the soil samples are shown in Fig. 3.

\subsection{Shear strength behaviors of shear zone soils}

Critical shear strength parameters (friction angle $\phi_{\mathrm{r}}$ (cohesion $c_{\mathrm{r}}$ is zero)) of soil are essential for stability analysis and design of countermeasures against the reactivation of landslides (Kimura et al. 2013). The shear strength parameters of the shear zone samples are determined based on Mohr Coulomb failure envelope, the shear strength as a function of effective normal stresses of samples Ch-04, Ch-06, and Ch-07 were analyzed after multistage multiphase ring shear test records. Results of the friction resistance value for shear zone samples are presented below.

The internal friction angle values $\left(\phi_{\mathrm{r}}\right)$ for each phase of the increasing shear displacement rate are shown in Fig. 4. Sample Ch-04 has the $\phi_{\mathrm{r}}$ value of $32.96^{\circ}$ (at initial phase), $35.65^{\circ}$ (at second phase), $33.36^{\circ}$ (at third phase), and $31.62^{\circ}$ (at last phase). The result indicates that the multiphase shear displacement rate caused the friction angle value to decrease progressively and reach residual state. The other sample (Ch-06) has the $\phi_{\mathrm{r}}$ value of $28.28^{0}$ (at initial phase), $28.51^{\circ}$ (at second phase), $29.78^{\circ}$ (at third phase), and $29.82^{\circ}$ (at last phase). In this case, the sample showed a steady state resistance developed to the entire shear process. However, sample Ch-07 has the $\phi_{\mathrm{r}}$ value of $29.27^{0}$ (at initial phase), $28.44^{\circ}$ (at second phase), $28.42^{\circ}$ (at third phase), and $33.38^{\circ}$ (at last phase). Sample Ch-07 has shown turbulent frictional resistance that has developed hardening effect at the last phase of shear mode compared to others (Fig. 5).

\subsection{Shear displacements and rate effects}

The shear deformation characteristics of samples are evaluated from the relationship between shear stress and shear displacement plots on different normal stresses, and continuous phases of shear mode. The results from the plot (Figs. 5 and 6) presents that samples do have varied post peak shear behaviors; soil softening (Ch-04), slight hardening (Ch-07) and remain steady state (Ch-06) property in the last phase of shear process. The shear stress against displacement shows some jagged features from peak to residual stresses during multiphase shear processes, for 
instance samples Ch-04 and Ch-07 have some fluctuations in shear stresses on the entire shear process, and sample Ch-06 looks steady comparatively. Li et al, (2017) reported that to determine the value of residual strength under high shear rate was difficult because of the obvious fluctuation of shear resistance in the shearing process from peak strength down to residual strength.

Many researchers indicated increment of the shear strength with the increment of an applied normal stresses (Alshameri et al. 2017). In addition, the decrement of the shear strength with the increment of the shear rate (Gratchev and Sassa 2015). Results of shear rate effects on the first stage of loading indicate that the shear weakening behavior for samples Ch-04 and Ch-06, and an increasing strength phenomenon (hardening effect) for sample Ch-07 under last phase shear processes. Meanwhile, on second stage of loading, samples Ch-06 and Ch-07 has shown increasing shear strength to the entire shear process. Moreover, on the last stage of loading, the residual friction resistance showed decreasing trends to all samples compared to initial loadings.

\subsection{Soil microstructure analysis and their implication on shear test}

Soil structure is characterized by observing the shape, size and arrangement of soil aggregates either microscopically or macroscopically. In microscopic technique, thin soil sections are examined under various types of microscopes for shape and size of the aggregates and voids. Further SEM imaging tests was performed to observe the post shear soil particle structures that may exhibit the particles arrangements and possible shear resistance behavior of shear zone soils. We plan to observe the micro structure grain arrangements of some samples that indicate the existence of significant shear hardening behavior, for instance sample Ch-07 on large shear displacement and rate effects.

The study site samples have showed some difference in terms their post peak shear behaviors under the multiphase shear processes. We plan to observe the micro structure grain arrangements of some samples that indicate the presence of significant shear hardening i.e. sample Ch-07 on large shear displacement and rate effects. In this study, the SEM images of sample Ch-07 was taken at the scales of $30 \mu \mathrm{m}$ in detail magnification (Fig. 8).

The SEM post shear image of Sample Ch-07 shows the existence of coarse to fine fractions, fragmentary grain alignments with spaces between particles, and some small sized particles aligned in a course of drive patterns. The particles have an elongated contact on varied ways of their faces and edges in plane view. The image view shows the different size and shape of particles that may contribute to the shear resistance developed. The resistance to crushing and rearrangement of particles along the shearing direction may cause to increase the shear torque during shear tests; it resulted in increased shear strength at high rate effects.

\section{Discussions}

The sliding zone soils are an essential part of landslides, and its studies thoroughly allied to the evolutionary development and landslide stability. Reactivated landslides could result from very slow to very rapid movements, such as those caused by earthquakes (Suzuki et al. 2017). The shear strength characteristics of soil samples from slip surface of reactivated landslide is evaluated by ring shear experimental method using multistage multiphase shear mode, it performs large displacement movement and increasing shear rate tests on shear zone samples.

The experimental results and plots show that the shear stress reach a peak value at initial or second phase shear displacement for the samples, and shown different post peak shear behaviors that consists of soil softening, slight hardening and remain steady state property in the last phase of shear process. The result of critical friction coefficients $\left(\tau_{c} / \sigma\right)$ values against the shear rate under multistage normal stress levels display decrease in critical shear strength as the normal stress increases, and show a pattern of frictional weakening behavior to reach residual conditions (samples Ch-04 and Ch-06). The influence of shear rate variation (Fukuoka and Sassa 1991; Jiang et al. 2016; Saito et al. 2006;

Page $7 / 20$ 
Scaringi and Di Maio 2016; Teuten 2012; Wang et al. 2010) on the critical state strength behavior was reported by several authors. Hu et al., (2018) reported that a rate-weakening behaviour was correlated to dramatic accelerations and extremely fast and destructive landslides (Lucas et al. 2014; Wang et al. 2017). In this study, the increased shear rate mode of experiment has disclosed the shear weakening behavior, which is similar with the above mentioned scholars' outcome and can narrate the long runout landslides.

Numerous frictional sliding studies of soils from slip surfaces yields a wide range of reported strengths. Sample Ch-07 has showed a shear hardening behavior during the entire shear processes, the friction resistance increased abruptly after third phase of shearing with turbulent flow of particles and this resistance persisted under the different normal stresses; however, it showed decrease in friction coefficient value on last stage loading, even though slight hardening phenomenon continued. According to Hu et al., (2018), the rate effect can play a fundamental role in the interpretation and forecasting of landslide behaviour (Leroueil 2001). In reactivated landslides, a rate-strengthening behaviour can prevent dramatic acceleration and long runout (Hu et al. 2018; Leroueil 2001; Wang et al. 2010). This hardening behavior can relate with the stabilization of long runout landslides.

Li et al., (2013) informed that the varying test results obtained for the relationship between the shearing rate and the residual shear strength of soil could possibly be due to material texture and modes of shear deformation. Based on ring shear tests on artificial mixtures of medium sand and powdered mica Lupini et al., (1981) reported observations on shear surfaces, and proposed three modes of residual shear behaviour: sliding, transitional and turbulent. They attributed the differential effects of shearing rates on residual shear strength to the shear mode, which is controlled by particle shape and the coefficient of inter particle friction (Li et al. 2013; Lupini 1981). Residual shear stresses vary depending on the soil particles characteristics, applied normal loads and shearing rates.

The SEM analysis has helped to observe and realize the post shear sample specimen microstructure and particle arrangement conditions in relation to their shear resistance on the image surface features. It can be observed that the particles arrangement is fragmented and has mixed grain size and shapes. Since the soil particles are sub-angular, the tendency of rolling or sliding between particles contacts may lead to increase shear resistance (Abd Rahman et al. 2016). The shear zone soils might expand with shearing processes, when the chains of grain particles rotate and produce an axial displacement comparable to the length of the grain chains and shearing displacement (Ferri et al. 2011). The fragmented and some parallel oriented particle arrangement after shear shows some general view on the shear resistance developed on particles resisted for sliding (Ch-07).

The shear strength of dense soils can show high shear resistance due to dilative behavior at large shear deformations and can fall back to the residual value when subjected to large displacement shear. Angularity and roughness enhance the dilative tendency of dense packing's. The shear strength and plastic flow (dilatancy) depend on the granular structure, particle sphericity and shear direction (Radjai and Az'ema 2009; Santamarina and Cho 2004). The particles interlocking creates resistance to grain to grain shear, rotate, roll and reorient along the shear directions, this kind of shear influences are recognized on microstructure features of the landslide shear zone soils.

\section{Conclusions}

Experiments demonstrate the residual shear behaviors which can reflect the kinematics and evolution of landslides. The following concluding points are made from this study.

- The use of multistage - multiphase shearing approach was suitable to evaluate residual shear behavior of slip zone samples, and enables to narrate the residual shear behavior of soil samples with the reactivation process of coseismic long runout landslides characteristics. 
- The critical state shear strength behavior of the slip zone samples have unveiled normally the shear weakening behaviors to last phase of shear mode. However, there is also a practical increase in residual friction coefficient values (hardening behavior) on the entire shear process as the rate increases for some sample (Ch-07), this scenario can be related with the stabilization mechanism of landslide slip surface soils.

\section{Declarations}

\section{Availability of data and materials}

All data generated or analyzed during this study are included in this published article.

\section{Competing interests}

The authors declare that they have no competing interests.

\section{Funding}

This research is supported by funds from the National Science Foundation of China under the Grants Nos. 41672307, 41790442 and 41702345 , Chinese Academy of Science.

\section{Authors' contributions}

EG as a first author, performed the Field investigation, sampling, experimental work, data analysis and Manuscript preparation. SQ and SG have carried out the field study and data analysis. Moreover, SQ and ZS have revised and polished the manuscript thoroughly to improve it. All authors read and approved the final manuscript.

\section{Acknowledgments}

The first author acknowledges CAS-TWAS presidential fellowship program, University of Chinese Academy of Sciences, Institute of Geology and Geophysics Chinese Academy of Sciences and Arba Minch University, for funding and allowing him for his Doctoral study (PhD). Special thanks presented to Prof. Shi Zhenming and Feng Shijin, for the provision and allowance of the Servo-controlled ring shear test experiment at Geotechnical department, Tongji University.

\section{Authors' information}

\section{Affiliations}

Key Laboratory of Shale Gas and Geoengineering, Institute of Geology and Geophysics, Chinese Academy of Sciences, Chaoyang District, Beijing, 100029, China

Institute of Earth Science, Chinese Academy of Sciences, Beijing, 100029, China

University of Chinese Academy of Sciences, Beijing, 100049, China

\section{$E G, S Q, S G$}

Department of Geology, Arba Minch University, P. O. Box 21, Arba Minch, 00251, Ethiopia

EG (current position - Assistant Professor)

Key Laboratory of Geotechnical and Underground Engineering of the Ministry of Education, Department of Geotechnical Engineering, Tongji University 


\section{References}

1. Abd Rahman N, Norsyahariati N, Ru Hui ND, Azmi Juliana K, Mohd Jaini AG, Yunus Z, R. \& Rahmat SN (2016) The Effect of Soil Particle Arrangement on Shear Strength Behavior of Silty Sand. MATEC Web of Conferences, 47, 03022, doi: 10.1051/matecconf/20164703022

2. Alshameri B, Madun A, Bakar I (2017) Assessment on the Effect of Fine Content and Moisture Content Towards Shear Strength. Geotechnical Engineering Journal of the SEAGS \& AGSSEA, 48

3. ASTM-D2487-11 (2011) Standard Practice for Classification of Soils for Engineering Purposes (Unified Soil Classification System). ASTM International, West Conshohocken, PA.

4. ASTM-D6467-13 (2013) Standard Test Method for Torsional Ring Shear Test to Determine Drained Residual Shear Strength of Cohesive Soils. ASTM International, West Conshohocken.

5. Bhat DR, Yatabe R, Bhandary NP (2013) Study of preexisting shear surfaces of reactivated landslides from a strength recovery perspective. J Asian Earth Sci 77:243-253. doi:10.1016/j.jseaes.2013.08.023

6. Bhattacharya G, Chowdhury RM, Subhadeep (2017) Residual factor as a variable in slope reliability analysis. Bull Eng Geol Env. doi:10.1007/s10064-017-1085-5

7. Binod T, Hideaki M (2004) Objective Oriented Multistage Ring Shear Test for Shear Strength of Landslide Soil. Journal of Geotechnical Geoenvironmental Engineering @ASCE 130:217-222. doi:10.1061//ASCE/10900241/2004/130:2/217

8. Bromhead E (1979) A simple ring shear apparatus. Ground Engineering, 12

9. Cui S, Wang G, Pei X, Huang R, Kamai T (2016) On the initiation and movement mechanisms of a catastrophic landslide triggered by the 2008 Wenchuan (Ms 8.0) earthquake in the epicenter area. Landslides. doi:10.1007/s10346-016-0754-y

10. Eid HT, Amarasinghe RS, Rabie KH, Wijewickreme D (2015) Residual shear strength of fine-grained soils and soilsolid interfaces at low effective normal stresses. Can Geotech J 52:198-210. doi:10.1139/cgj-2014-0019

11. Ferri F, Di Toro G, Hirose T, Han R, Noda H, Shimamoto T, Quaresimin M, de Rossi N (2011) Low- to high-velocity frictional properties of the clay-rich gouges from the slipping zone of the 1963 Vaiont slide, northern Italy. J Geophys Res, 116, doi:10.1029/2011jb008338

12. Fukuoka H, Sassa K (1991) High-speed High-Stress Ring Shear Tests on Granular Soils and Clayey Soils. USDA Forest Service Gen. Tech. Rep. PSW-GTR-130

13. Getahun E, Qi S-w, Guo S-f, Zou Y, Liang N (2019) Characteristics of grain size distribution and the shear strength analysis of Chenjiaba long runout coseismic landslide. J Mt Sci 16:2110-2125. doi:10.1007/s11629-019-5535-3

14. Gratchev IB, Sassa K (2015) Shear Strength of Clay at Different Shear Rates. J Geotech GeoEnviron Eng 141:06015002. doi:10.1061/(asce)gt.1943-5606.0001297

15. Habibbeygi F, Nikraz H (2018) Effect of shear rate on the residual shear strength of pre-sheared clays. Cogent Geoscience, 4, doi:10.1080/23312041.2018.1453989

16. Harris A, Watson P (2003) Optimal procedure for the ring shear test. Ground Eng., 30

17. Hoyos LR, Velosa CL, Puppala AJ (2010) A Novel Suction-Controlled Ring Shear Testing Apparatus for Unsaturated Soils. Geotechnical Special Publication No 202, GeoShanghai 2010 International Conference

18. Hoyos LR, Velosa CL, Puppala AJ (2014) Residual shear strength of unsaturated soils via suction-controlled ring shear testing. Eng Geol 172:1-11. doi:10.1016/j.enggeo.2014.01.001

Page 10/20 
19. Hu W, Scaringi G, Xu Q, Van Asch TWJ, Huang R, Han W (2018) Suction and rate-dependent behaviour of a shearzone soil from a landslide in a gently-inclined mudstone-sandstone sequence in the Sichuan basin. China Engineering Geology 237:1-11. doi:10.1016/j.enggeo.2018.02.005

20. Huang T, Ding M-t, She T, Tian S-j, Yang J-t (2017) Numerical simulation of a high-speed landslide in Chenjiaba, Beichuan, China. J Mt Sci 14:2137-2149. doi:10.1007/s11629-017-4516-7

21. Hvorslev MJ (1939) Torsion shear tests and their place in the determination of the shearing resistance of soils. Proc. Am. Soc. for Testing Materials, 39, 999-1022

22. Jiang Y, Wang G, Kamai T (2016) Fast shear behavior of granular materials in ring-shear tests and implications for rapid landslides. Acta Geotech. doi:10.1007/s11440-016-0508-y

23. Kalteziotis N (1993) The residual shear strength of some Hellenic clayey soils. Geotech Geol Eng 11:125-145

24. $10.1007 / \mathrm{s} 10346-013-0457-6$

Kimura S, Nakamura S, Vithana SB, Sakai K (2013) Shearing rate effect on residual strength of landslide soils in the slow rate range. Landslides, (C) Springer-Verlag, doi: 10.1007/s10346-013-0457-6

25. Kitajima H, Chester JS, Chester FM, Shimamoto T (2010) High-speed friction of disaggregated ultracataclasite in rotary shear: Characterization of frictional heating, mechanical behavior, and microstructure evolution. J Geophys Res, 115, doi:10.1029/2009jb007038

26. Leroueil S (2001) Natural slopes and cuts: Movement and faailure mechanisms. Geotechnique 51:197-243

27. Li D, Yin K, Glade T, Leo C (2017) Effect of over-consolidation and shear rate on the residual strength of soils of silty sand in the Three Gorges Reservoir. Sci Rep 7:5503. doi:10.1038/s41598-017-05749-4

28. 10.1680/geng.11.00013

Li Y, Chan LS, Yeung AT, Xiang X (2013) Effects of test conditions on shear behaviour of composite soil.

Proceedings of the Institution of Civil Engineers - Geotechnical Engineering, 166, 310-320, doi:

10.1680/geng.11.00013

29. Lucas A, Mangeney A, Ampuero JP (2014) Frictional velocity-weakening in landslides on Earth and on other planetary bodies. Nature communication. doi:10.1038/ncomms4417

30. Lupini JF (1981) The residual strength of soils. PhD, University of London (Imperial College of Science and Technology)

31. Mackay R, Xue J, Powrie W, Dent B (2012) A New Ring Shear Apparatus for determination of the Residual Shear Resistance of Remoulded Brown Coal. Australian Geomechanics, 47

32. Mairaing W (2008) Landslide problems and warning by geotechnical methods. 26th Conference of the ASEAN Federation of Engineering Organization

33. Meehan CL, Brandon TL, Duncan JM (2008) Measuring "Fast" Shear Strengths Along Slickensided Surfaces in the Bromhead Ring Shear. Geotechnical Testing Journal ASTM 31:239-242. doi:10.1520/GTJ101325)

34. Meehan CL, Brandon TL, Duncan JM (2007) Measuring Drained Residual Strengths in the Bromhead Ring Shear. Geotechnical Testing Journal ASTM 30:466-473. doi:10.1520/GTJ101017)

35. Mersi G, Olson RE (1970) Shear strength of Montmorillonite Geotechnique 20:261-270

36. Mesri G, Shahien M (2003) Residual Shear Strength Mobilized in First-Time Slope Failures. Journal of Geotechnical Geoenvironmental Engineering (CASCE 129:12-31. doi:10.1061//ASCE/1090-0241/2003/129:1/12

37. Nam S, Gutierrez M, Diplas P, Petrie J (2011) Determination of the shear strength of unsaturated soils using the multistage direct shear test. Eng Geol 122:272-280. doi:10.1016/j.enggeo.2011.06.003

38. Radjai F, Az'ema E (2009) Shear strength of granular materials. European Journal of Environmental Civil Engineering Ed Lavoisier 13:203-218

Page $11 / 20$ 
39. Saito R, Fukuoka H, Sassa K (2006) Experimental Study on the Rate Effect on the Shear Strength. Universal Academy Press, Inc. / Tokyo, Japan, 421-427

40. Santamarina JC, Cho GC (2004) Soil behaviour: The role of particle shape. Proc. Skempton Conf., London

41. Scaringi G, Di Maio C (2016) Influence of Displacement Rate on Residual Shear Strength of Clays. Procedia Earth Planetary Science 16:137-145. doi:10.1016/j.proeps.2016.10.015

42. Setiawan H, Takara K, Kyoji S, Miyagi T (2015) Shear Strength Reduction in Progress of Shear Displacement on the Landslide Near Dam Reservoir. Procedia Environmental Sciences 28:587-594.

doi:http://dx.doi.org/10.1016/j.proenv.2015.07.069

43. Stark N, Hay AE, Cheel R, Lake CB (2014) The impact of particle shape on the angle of internal friction and the implications for sediment dynamics at a steep, mixed sand-gravel beach. Earth Surf Dyn 2:469-480. doi:10.5194/esurf-2-469-2014

44. Stark TD, Contreras IA (1996) Constant Volume Ring Shear Apparatus. Geotechnical Testing Journal GTJODJ 19:311

45. Modified Bromhead ring shear apparatus Stark TD, Eid HT (1993) Modified Bromhead ring shear apparatus

46. Stark TD, Vettel JJ (1992) Bromhead Ring Shear Test Procedure: ASTM. Geotechnical Testing Journal. GTJODJ. Copyright American Society for Testing and Materials, 1916 Race Street, Philadelphia, PA 19103, 15, 24-32

47. Suzuki M, Van Hai N, Yamamoto T (2017) Ring shear characteristics of discontinuous plane. Soils Found 57:1-22. doi:10.1016/j.sandf.2017.01.001

48. Teuten JM (2012) Shear Characteristics of Soils with Varying Silt/Clay Fractions. Imperial College London, Civil and Environmental Engineering Student Conference

49. Tiwari B, Ajmera B (2011) A new correlation relating the shear strength of reconstituted soil to the proportions of clay minerals and plasticity characteristics. Appl Clay Sci 53:48-57. doi:10.1016/j.clay.2011.04.021

50. Tiwari B, Brandon TL, Marui H, Tuladhar GR (2005) Comparison of Residual Shear Strengths from Back Analysis and Ring Shear Tests on Undisturbed and Remolded Specimens. Journal of Geotechnical Geoenvironmental Engineering @ASCE 131:1071-1079. doi:10.1061//ASCE/1090-0241/2005/131:9/1071

51. Wang G, Suemine A, Schulz WH (2010) Shear-rate-dependent strength control on the dynamics of rainfall-triggered landslides, Tokushima Prefecture, Japan. Earth Surface Processes and Landforms, n/a-n/a, doi: 10.1002/esp.1937

52. Wang YF, Dong JJ, Cheng QG (2017) Velocity-dependent frictional weakening of large rock avalanche basal facies: Implications for rock avalanche hypermobility? Journal of Geophysical Research: Solid Earth.

doi:10.1002/2016jb013624

53. Wen B, Ji B (2019) Variation in Residual Strength of the Large-Scale Landslides' Slip Zones in the Three Gorges Reservoir of China. 11-18, doi: 10.1007/978-3-319-93124-1_2

54. Wen BP, Aydin A (2004) Deformation History of a Landslide Slip Zone in Light of Soil Microstructure. Environmental \& Engineering Geoscience, $\mathbf{X}, 123-149$

55. Wu S, Wang T, Shi L, Sun P, Shi J, Li B, Xin P, Wang H (2010) Catastrophic landslides triggered by the 2008 Wenchuan earthquakes. China J Eng Geol 18:145-159

56. Xing A, Wang G, Li B, Jiang Y, Feng Z, Kamai T (2015) Long-runout mechanism and landsliding behaviour of large catastrophic landslide triggered by heavy rainfall in Guanling, Guizhou, China. Can Geotech J 52:971-981. doi:10.1139/cgj-2014-0122

57. Yin Y, Xing A, Wang G, Feng Z, Li B, Jiang Y (2016) Experimental and numerical investigations of a catastrophic long-runout landslide in Zhenxiong, Yunnan, southwestern China. Landslides 14:649-659. doi:10.1007/s10346016-0729-z

Page 12/20 
58. Yong L, Chengmin, Huang, Baoliang W, Xiafei, Tian, Jingjing L (2017) A unified expression for grain size distribution of soils. Geoderma 288:105-119. doi:10.1016/j.geoderma.2016.11.011

\section{Figures}
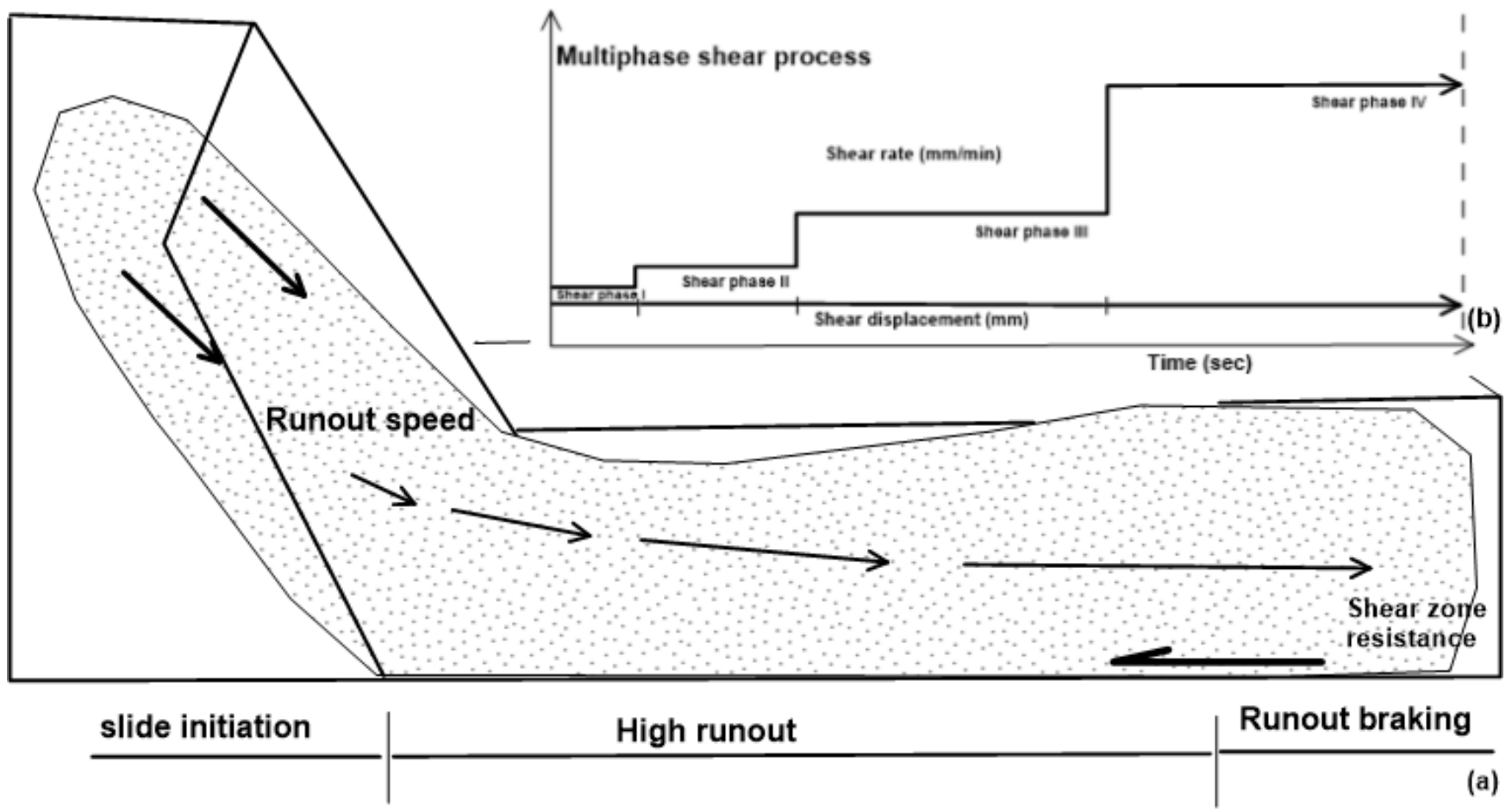

Figure 1
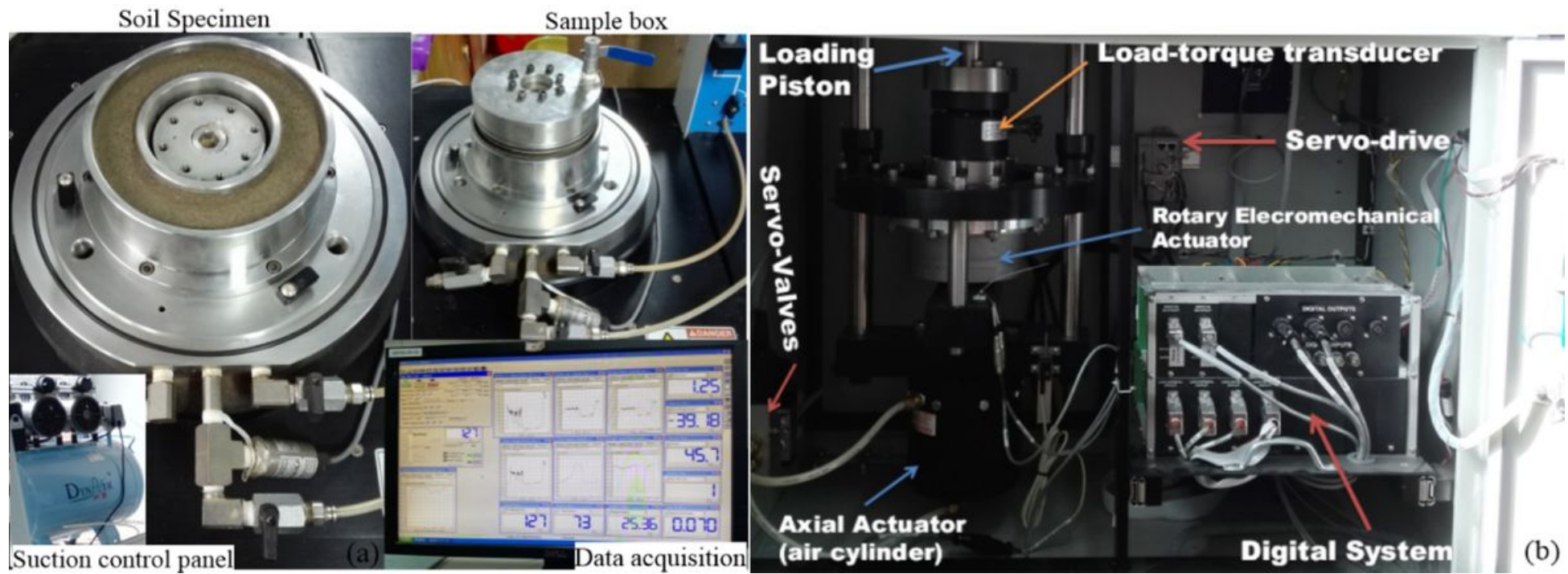

Figure 2 


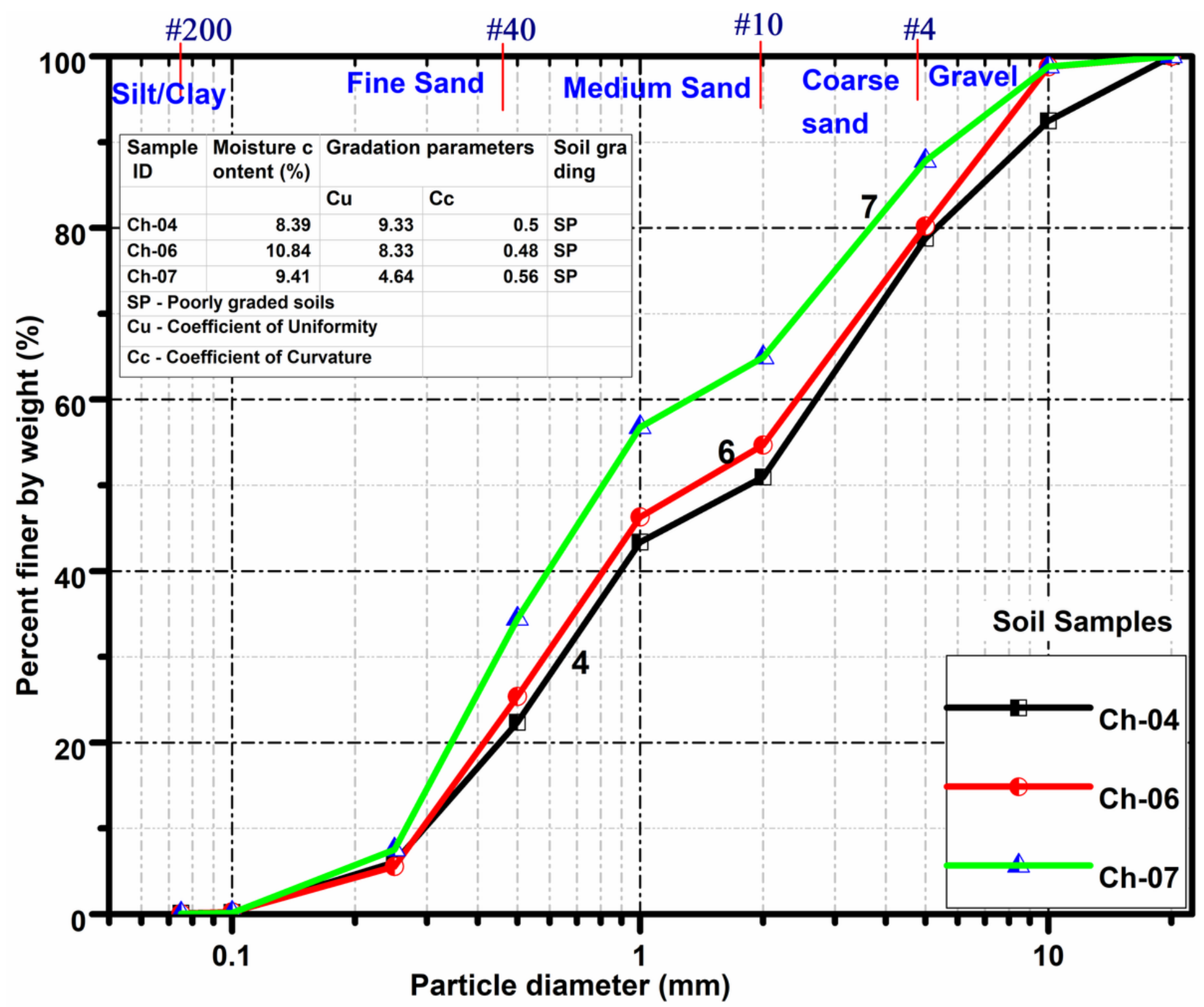

Figure 3
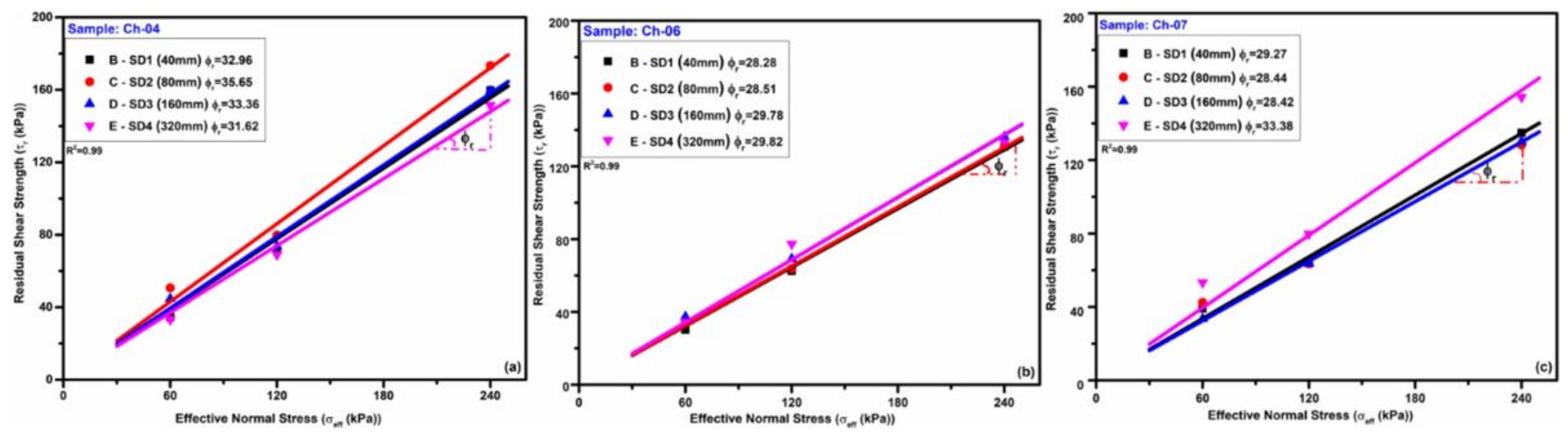

Figure 4 


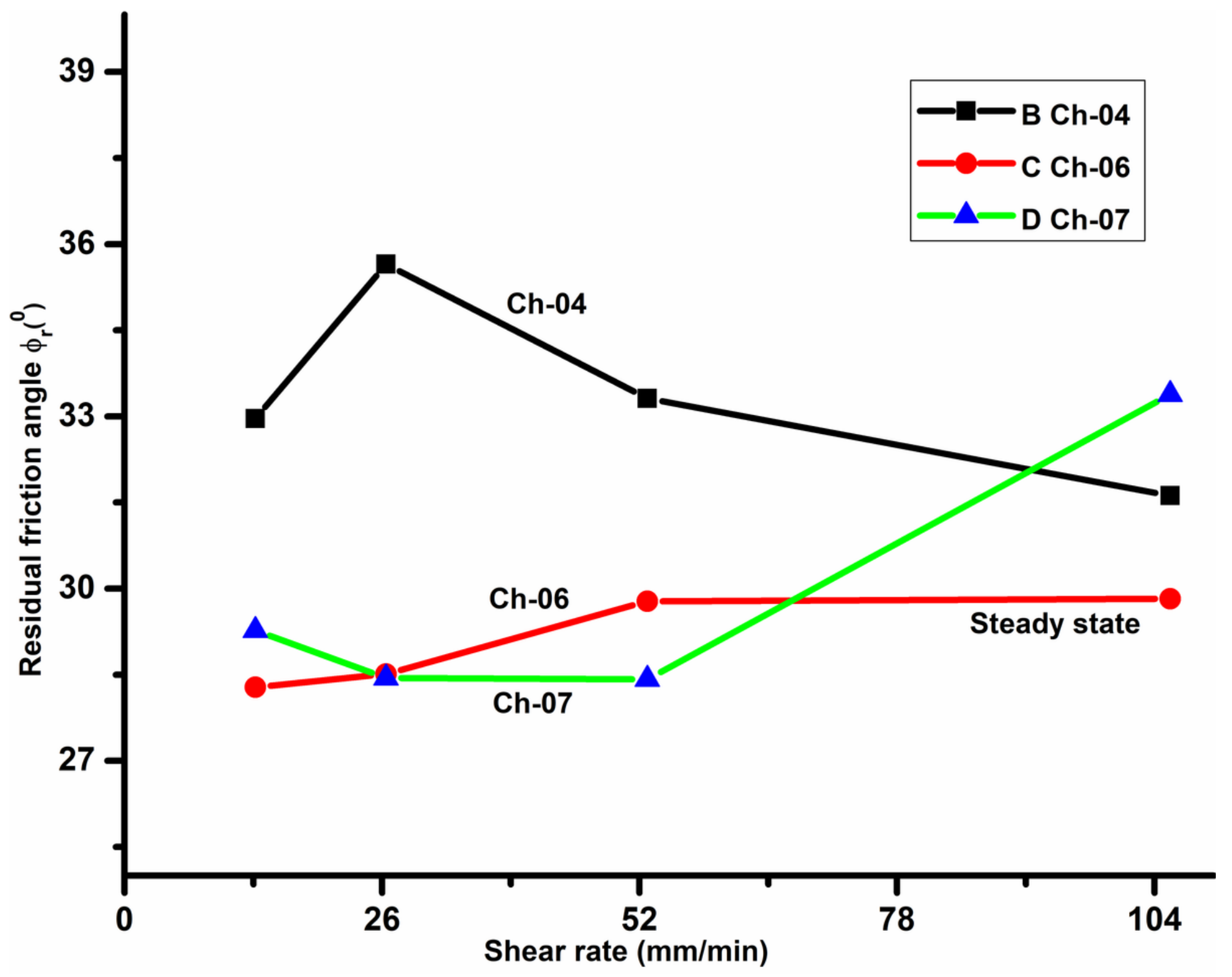

Figure 5
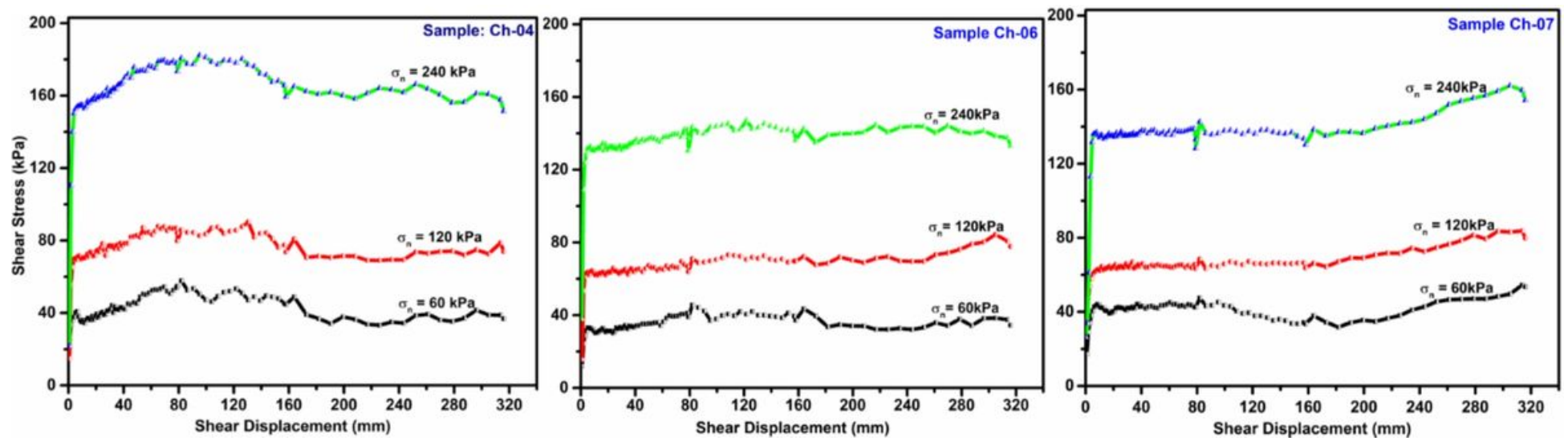

Figure 6 

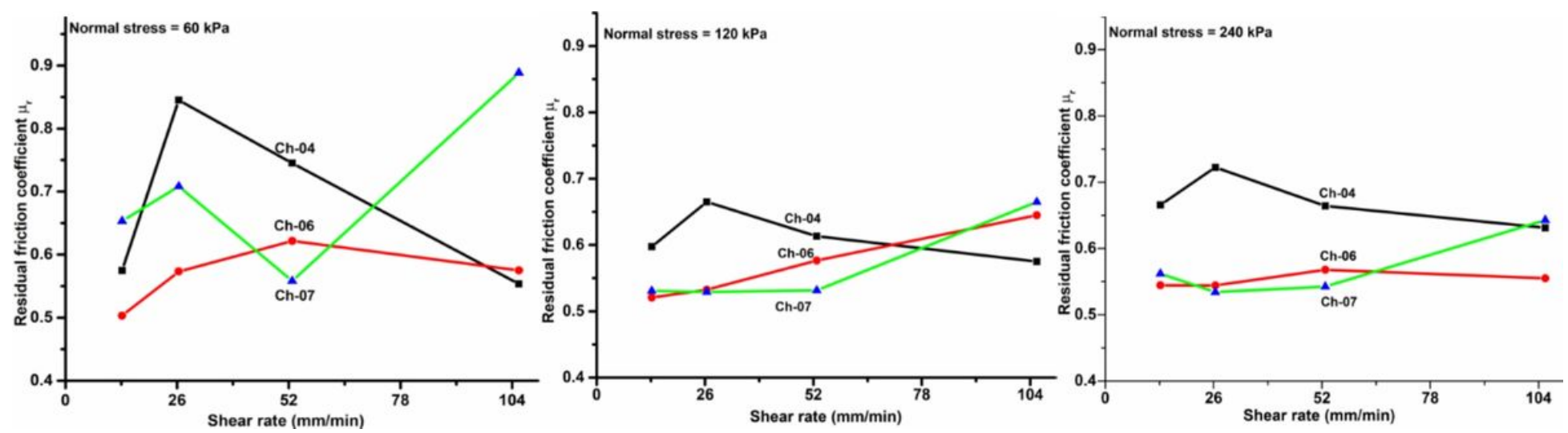

Figure 7

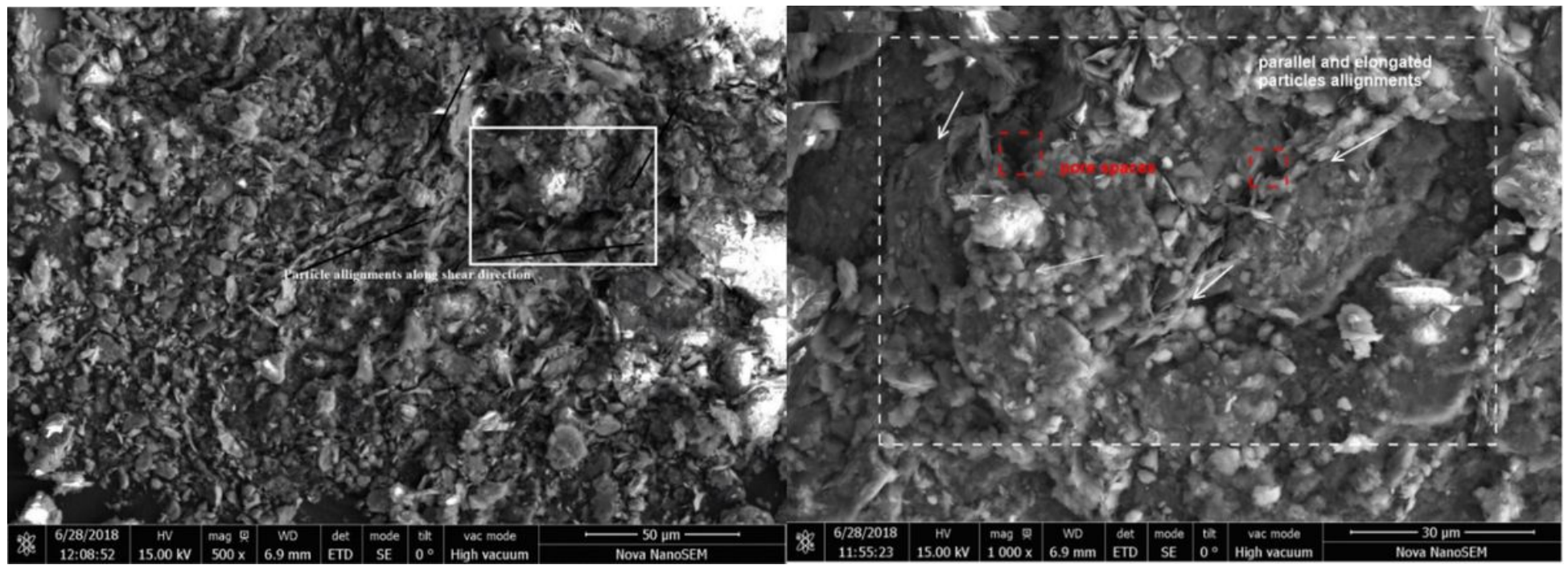

Figure 8

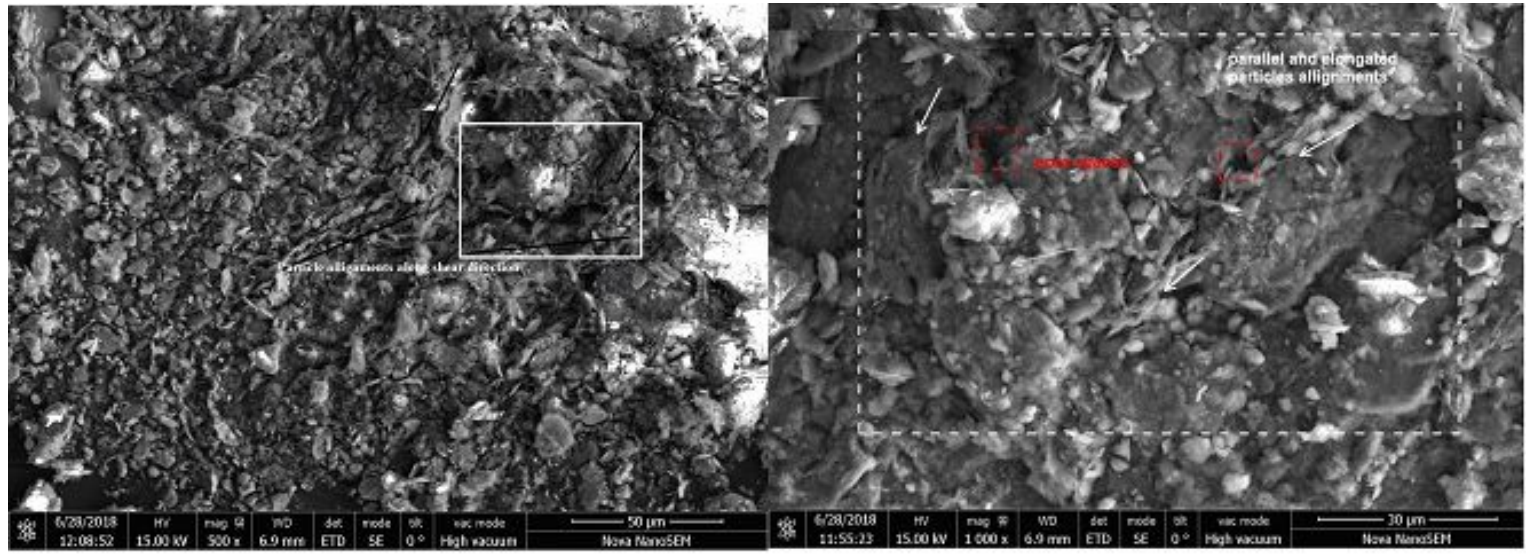

\section{Figure 9}

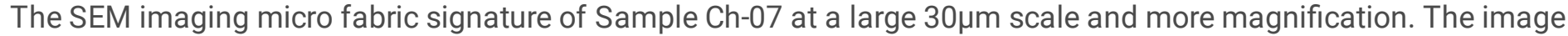
displays mixtures of coarse and fine fractions with different fragmentation style and certain parallel aligned particles. 

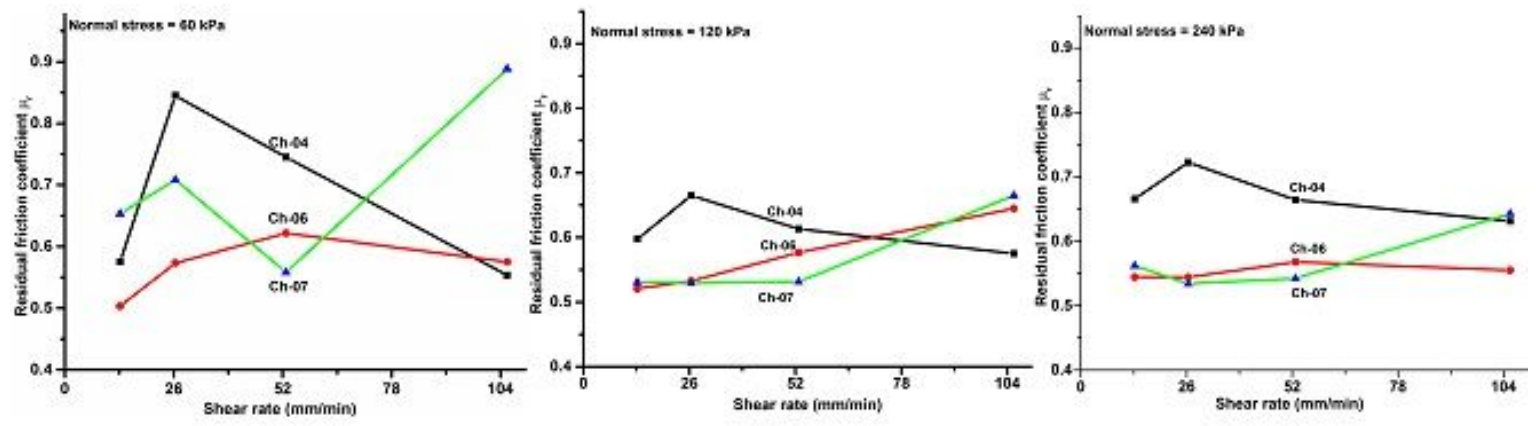

Figure 10

Patterns of the residual friction coefficients as a function of increasing shear rate under multistage normal stresses.
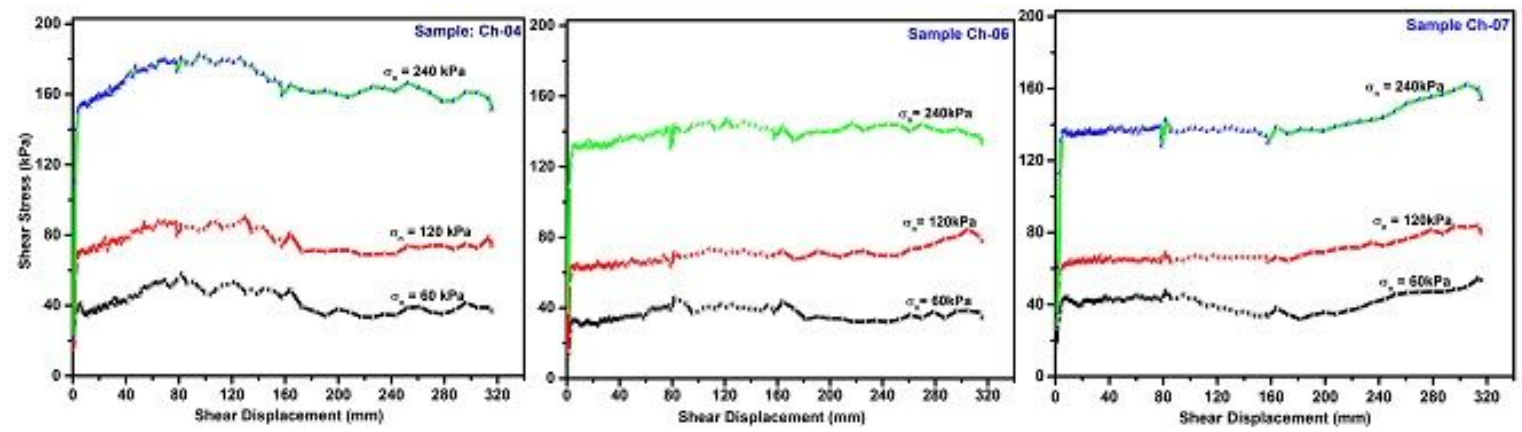

Figure 11

The relationship of shear stress and shear displacement of soil samples. Plot shows (a) for sample Ch-04; (b) for sample Ch-06; (c) for sample Ch-07. 


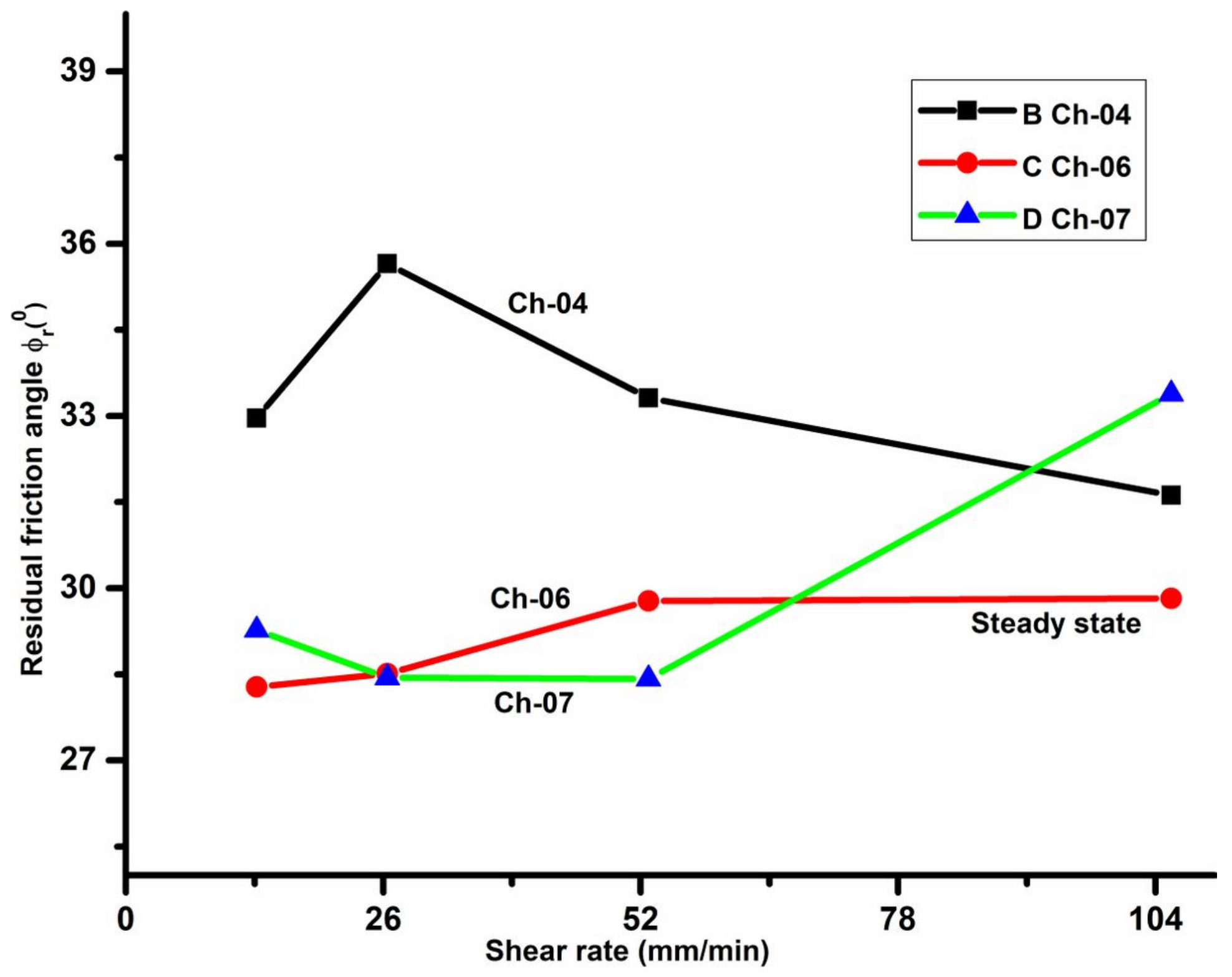

Figure 12

Analysis of the residual friction angle values with incremental multiphase shear rate effects. The plot show varied residual shear behavior; friction weakening (Ch-04), hardening effect (Ch-07) and a steady state (Ch-06) behaviors.
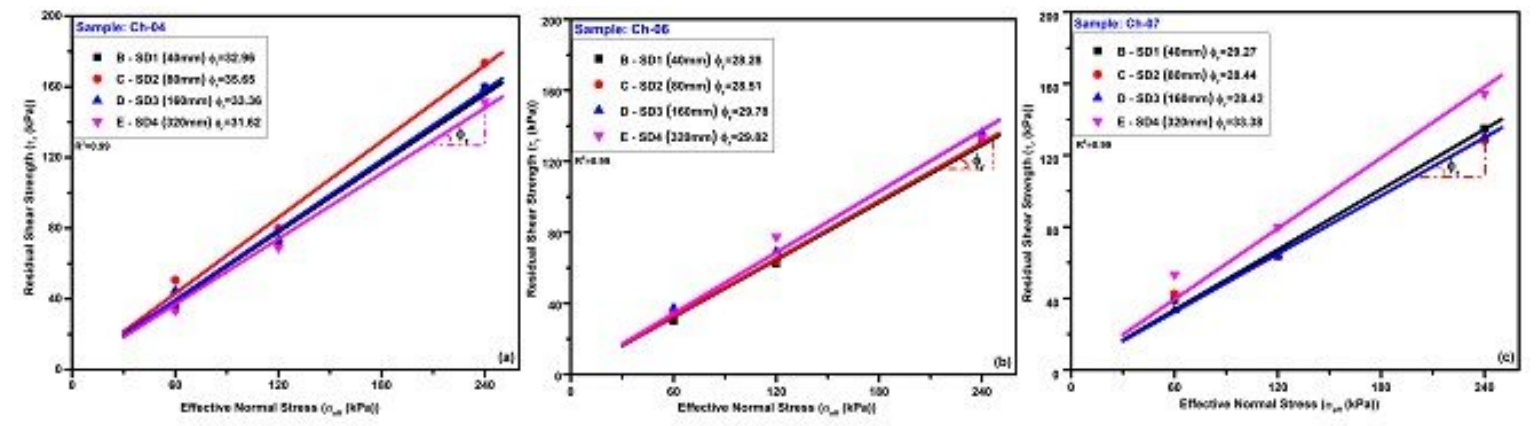

Figure 13

Plot showing the critical shear strength parameters of the shear zone samples using multiphase shear tests. The shear envelopes show (a) for sample of Ch-04; (b) for sample of Ch-06; and (c) for sample of Ch-07. 


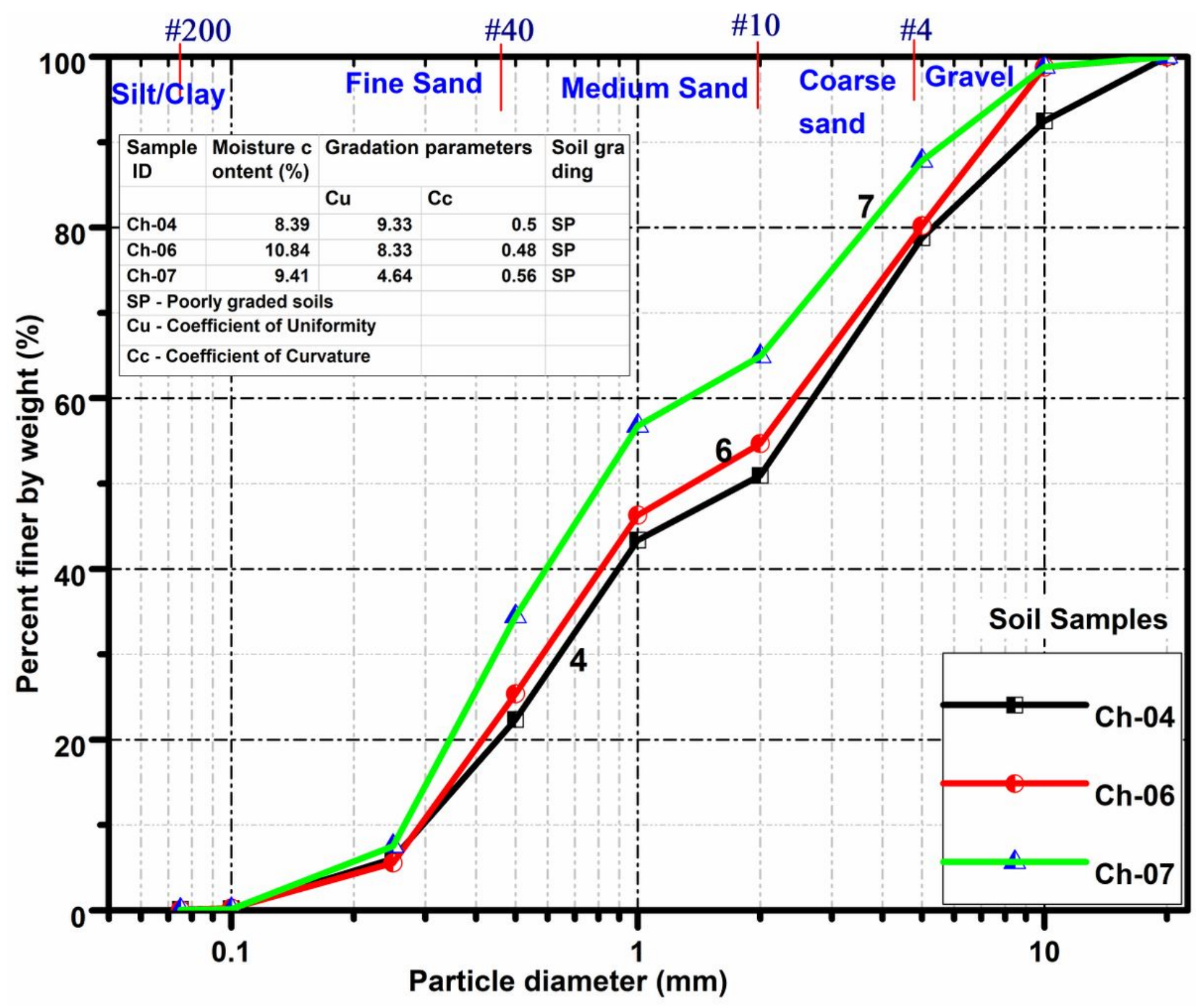

Figure 14

Grain size distribution curve of representative shear zone soil samples.

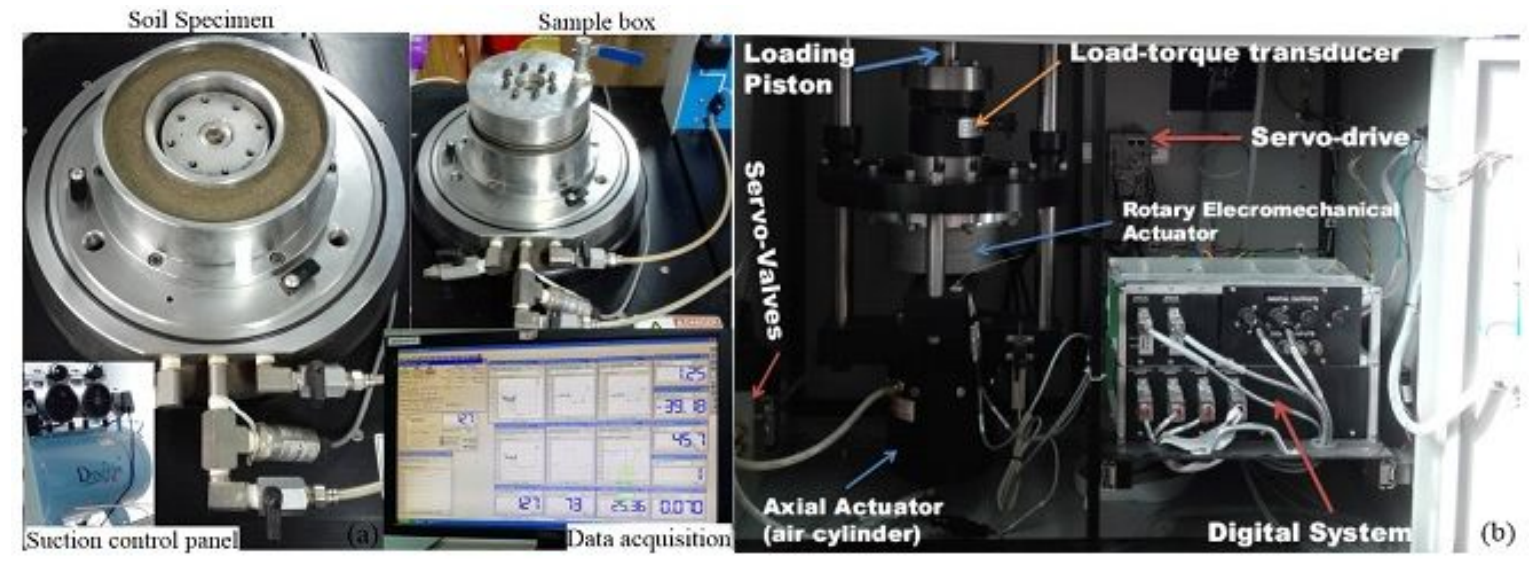

Figure 15 
Automated servo controlled load-torque ring shear testing apparatus outlook, (a) Suction control ring shear apparatus view with sample box and data acquisition (b) Picture showing the Main cell component details. After (Getahun et al. 2019)

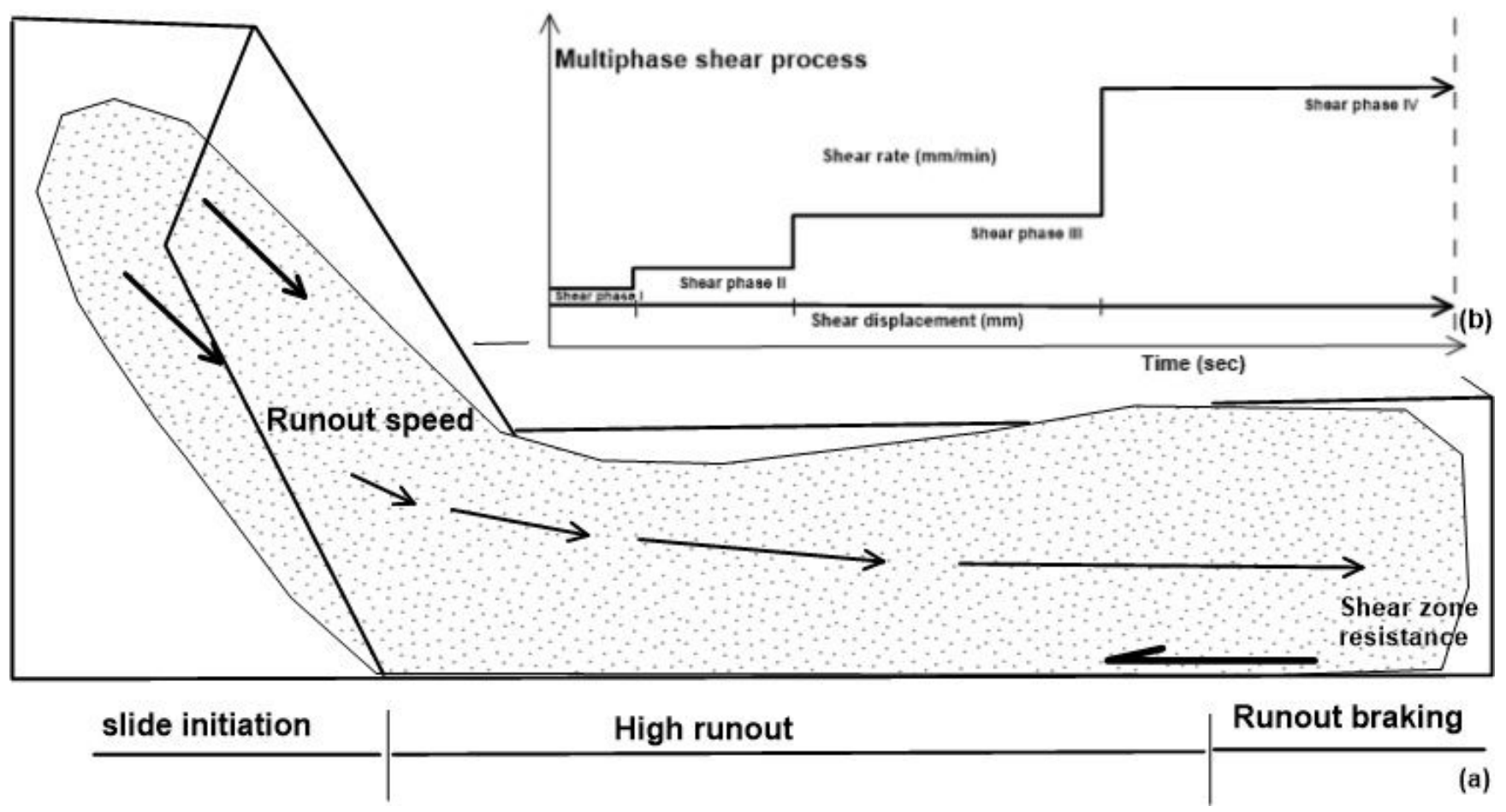

Figure 16

(a) Conceptual sketch of Long runout landslide failure mechanism and (b) designed multiphase shear process to experiment the residual shear behavior of the reactivated landslide soils. 